\title{
Pengaruh Lingkungan Institusional Dan Kinerja Keuangan Terhadap Opini Auditor Pada Perusahaan Manufaktur
}

\author{
Mos Indrawati ${ }^{1}$ \\ H. Ahmad Rifai ${ }^{2}$ \\ M. Irwan, $\mathrm{MP}^{3}$ \\ ${ }^{1,2,3}$ Fakultas Ekonomi dan Bisnis Universitas Mataram, (Unram), NTB, Indonesia \\ e-mail : mosindrawati79@gmail.com
}

\begin{abstract}
ABSTRAK
Penelitian ini bertujuan untuk mendapatkan bukti empiris tentang dampak kinerja keuangan dan lingkungan institusional pada pendapat audit WTP. Lingkungan Institusional diproksikan sebagai lingkungan institusional yang lemah dan kuat. Alat ukur AltmanZ' Score digunakan dalam mengukur kinerja keuangan. Pendapat auditor dibagi dalam opini audit WTP dan opini audit non WTP. Metode purposive sampling digunakan dalam pengambilan sampel penelitian dengan beberapa kriteria objek sehingga diperoleh 146 perusahaan. Regresi logistic digunakan dalam menganalisis data penelitian dengan program SPSS23.0 dalam pengujian hipotesisnya. Penelitianmemperoleh kesimpulan bahwa lingkungan institusional tidak memiliki pengaruh yang signifikan pada penerimaan opini audit WTP suatu perusahaan, dan kinerja keuangan dapat mempengaruhi opini audit WTP suatu perusahaan.
\end{abstract}

Kata kunci: Lingkungan institusional, kinerja keuangan, opini audit WTP.

\begin{abstract}
This study aims to obtain empirical evidence about the impact of financial performance and institutional environment on WTP audit opinion. Institutional environment is proxied as a weak institutional environment and. strong. Altman $Z$ 'Score measuring instruments are used to measure financial performance. Auditors' opinions are divided into WTP audit opinions and non WTP audit opinions. The purposive sampling method was used in taking research samples with several object criteria to obtain 146 companies. Logistic regression is used in analyzing research data with the SPSS 23.0 program in testing the hypothesis. The study concluded that the institutional environment does not have a significant influence on the acceptance of WTP audit opinion of a company, and financial performance can influence the WTP audit opinion of a company.
\end{abstract}

Keywords: Institutional environment, financial performance, WTP audit opinion.

\section{PENDAHULUAN}

Kinerja manajemen perusahaan dapat diukur melalui laporan keuangannnya. Laporan keuangan merupakan pertanggungjawaban suatu perusahaan dalam hal ini pihak manajemen. Adanya pelaporan keuangan berguna dalam memberikan informasi kepada para pemakai informasi, baik pihak dalam perusahaan maupun 
pihak luar perusahaan untukmenetapkan suatu putusan yang akan diambil. Hasil dari suatu kegiatan perusahaan tercermin pada laporan keuangan, dimana laporan keuangan ini harus diaudit, sebab laporan keuangan yang belum diaudit terdapat kemungkinan adanya keraguan bagi para pemakai tentang kewajarannya.

Prinsip-prinsip akuntansi harus diperhatikan dalam pemeriksaan terhadap laporan keuangan sebagai suatu hal yang wajar dilakukan dalam dunia bisnis terutama perusahaan yang besar dan sudah go public. Pemerikasaan ini harus dilakukan oleh seorang yang memiliki kapabilitas, agar keterangan-keterangan yang dilaporkan sesuai standar ketentuan yang berlaku, sehingga diterbitkan laporan audit sebagai ketetapan akhir dari suatu proses pemeriksaan ini.

Menurut Agoes (2012) menyatakan bahwa "Suatu pemeriksaan yang dilakukan secara kritis dan sistematis oleh pihak yang independen, terhadap laporan keuangan yang telah disusun oleh manajemen beserta catatan-catatan pembukuan dan bukti-bukti pendukungnya, dengan tujuan untuk dapat memberikan pendapat mengenai kewajaran laporan keuangan tersebut.”

Menurut Mulyadi (2014) bahwa proses auditing adalah proses yang secara teratur untuk menemukan dan melakukan penilaian terhadap bukti secara wajar tentang keterangan-keterangan peristiwa ekonomi dengan maksud untuk menentukan sinkronisasi antara keterangan-keterangan dengan standar yang ditentukan serta menginformasikan hasilnya kepada pihak yang membutuhkan.

Menurut SPAP (Standar Profesional Akuntan Publik), bahwa tipe pendapat auditor dibedakan menjadi 5, yaitu : pertama opini WTP dimana posisi keuangan, hasil usaha, dan cash flows, dalam semua hal yang material disajikan 
secara wajar sesuai standar akuntansi yang berlaku umum di Indonesia ; kedua WTP dengan menambahkan paragraf penjelas ; ketiga opini wajar dengan pengecualian yaitu mengungkapkan secara wajar sesuai standar akuntansi kecuali untuk dampak hal-hal yang berhubungan dengan yang dikecualikan ; keempat pendapat tidak wajar dimana laporan keuangan tidak disajikan secara wajar sesuai standar yang berlaku; Pernyataan tidak memberikan pendapat dimana auditor tidak menyatakan pendapat atas laporan keuangan.

Pemeriksaan laporan keuangan perusahaan harus berpatokan pada standar akuntansi yang berlaku dalam merumuskan suatu opini atas laporan keuangan oleh akuntan dalam memberikan pendapat secara wajar suatu laporan keuangan perusahaan. Seorang auditor memberikan pendapatnya terhadap perusahaan kliennya dimana opini WTP merupakan opini yang mayoritas paling banyak diperoleh yang disebabkan oleh pengaruhi politik suatu negara (Zahra dan Chariri, 2013).

Dalam suatu periode akuntansi dimana terdapat suatu pertanggungjawaban pihak manajemen berupa suatu laporan keuangan perusahaan. Untuk menjamin suatu laporan keuangan dapat dipertanggungjawabkan sehingga menjadi suatu pedoman dalam menetapkan suatu keputusan yang akan diambil, maka dalam hal ini diperlukan pihak yang dianggap kompeten yang dapat menjamin kewajaran laporan keuangannya. Opini WTP merupakan opini yang paling baik bagi suatu entitas atas laporan keuangan suatu perusahaan. Akan tetapi menurut ( Zahra dan Chariri (2013), bahwa opini WTP yang diperoleh suatu entitas bukanlah jaminan bahwa entitas tersebut telah berkinerja baik, dan terbebas dari korupsi, kolusi, dan 
nepotisme. Menurut Budijono, (2012) masalah ini terjadi karena dalam memberikan pendapat wajar berdasarkan pada laporan keuangan historis sebagaimana yang terdapat dalam opini general audit, bukan pemeriksaan untuk tujuan khusus.

Beberapa penelitian telah dilakukan untuk melihat beberapa faktor yang pengaruh Opini Auditor. Penelitian Chan, et al., (2010) melakukan penelitian di China tentang pengaruh lingkungan dengan obyek penelitian perusahaan BUMN dan Non BUMN, menyatakan bahwa salah satu yang mempengaruhi opini audit adalah lingkungan institusional. Ketika pemerintah lokal mengendalikan sebagian besar saham perusahaan maka auditor memiliki kemungkinan yang lebih besar untuk mengeluarkan pendapat wajar tanpa pengecualian pada lingkungan institusional yang lemah. Dimana informasi akuntansi dunia, srtruktur kepemilikan perusahaan dan pasar uang ditentukan oleh hukum, lembaga pemerintahan, ekonomi, akuntansi dan politik suatu Negara (Zahra dan Chariri (2013).

Sementara Zahra dan Chariri (2013) melakukan penelitian di Indonesia pada beberapa perusahaan BUMN maupun Non BUMN pula, menemukan bahwa lingkungan institusional mempengaruhi Opini auditor secara signifikan. Lingkungan institusional suatu entitas dibedakan dalam dua lingkungan yaitu mengambil wilayah DKI Jakarta sebagai ibu kota dan non DKI Jakarta sebagai ibu kota. Dalam penelitiannya Zahra dan Chariri menekankan bahwa Ibukota Jakarta merupakan pusat kegiatan bisnis dan pusat pemerintahan di Indonesia. Berdasarkan karakteristik lingkungan institusional yang terdapat pada penelian- 
penelitian sebelumnya, maka penulis mendefinisikan bahwa lingkungan institusional merupakan lingkungan dimana alamat kantor pusat suatu perusahaan berada.

Beberapa penelitian lain melihat pengaruh kinerja keuangan suatu perusahaan terhadap opini auditor. Aprinia dan Hermanto (2016) adalah melakukan penelitian tentang pengaruh rasio likuiditas sebagai rasio keuangan perusahaan terhadap opini auditor, dimana opini auditor yang diteliti adalah opini auditor going concern dan menemukan bahwa rasio likuiditas secara signifikan mempengaruhi opini audit.

Menurut Diakomihalis (2012) dalam Edy dan Tania (2018), bahwa Altman menggunakan perusahaan manufaktur yang go-public dalam penelitiannya terhadap model pertama Altman Z Score. Selanjutnya Altman melakukan pengembangan pada model pertamanya agar dapat diterapkan pada perusahaan industri swasta dan perusahaan non-industri, serta perusahaan sektor jasa yang dikenal dengan Model Altman Z'Score. Dalam penelitian yang telah dilakukan pada perusahaan industri logistik di India, Tyagi (2014) menggunakan model altman sebagai alat untuk mengukur tingkat kesehatan perusahaan. Ardiani et al., (2012) melakukan penelitian dengan menggunakan model Altman sebagai alat untuk mengukur kondisi keuangan. Hasil penelitiannya menemukan bahwa ternyata penerimaan opini audit tidak dipengaruhi oleh kondisi keuangan suatu perusahaan. Putrady dan Haryanto (2014) dalam penelitiannya menemukan tentang probabilitas penerimaan opini going concern dipengaruhi secara signifikan oleh kondisi keuangan perusahaan. 
Lingkungan institusional di sekitar organisasi dapat membentuk organisasi itu sendiri ( Gudono, 2009). Menurut Teori institusional, institusi diluar organisasi mempengaruhi perilaku organisasi. Menurut ( Meyer dan Rowan, 1977) kebijakan, prosedur organisasi modern, posisi dan program dipengaruhi oleh pandangan konstituen, pengetahuan dan opini publik, melalui pengadilan, hukum, prestis social dan sistem pendidikan. Sementara Teori Lingkungan Institusional menurut ( DiMaggio dan Powell (1983), untuk mempertahankan legitimasinya dan untuk dapat bertahan, sebaiknya suatu organisasi selayaknya mengkombinasikan antara nilai-nilai budaya dan sosial. Menurut teori Institusional bahwa kekuatan politik, budaya, dan sosial sekitar organisasi mempengaruhi perilaku auditor. Sehingga teori Institusional relevan digunakan dalam penelitian ini.

Beberapa penelitian sebelumnya dengan memperoleh hasil yang berbedabeda, sehingga penulis termotivasi untuk meneliti tentang dampak lingkungan dan kondisi keuangan perusahaan terhadap opini auditor, yang mana opini auditor pada kasus ini lebih khusus mengenai opini auditor wajar tanpa pengecualian (WTP) dengan mengambil obyek yang berbeda dengan penelitian sebelumnya. Pada Gambar 1 menunjukkan model penelitian secara konseptual.

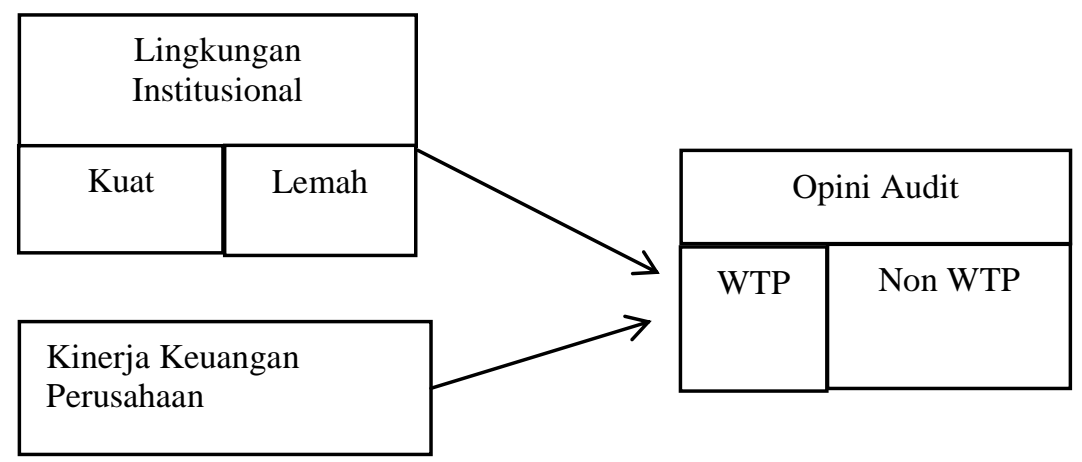

Gambar 1. Kerangka Konseptual Penelitian 
Menurut teori institusional bahwa lingkungan suatu organisasi sangat menentukan suatu perusahaan karena merupakan entitas terbuka.Hasil penelitian yang dilakukan oleh Chan et al,. (2010) Suatu perusahaan yang berada pada lingkungan institusional lemah memiliki kemungkinan yang lebih besar untuk memperoleh pendapat wajar tanpa pengecualian dibandingkan dengan perusahaan yang berada pada lingkungan institusional kuat.Sementara hasil penelitian yang dilakukan oleh Zahra dan Chariri (2013) menyatakan bahwa auditor dalam memberikan opini WTP secara signifikan sangat ditentukan oleh suatu lingkungan institusional dan memiliki hubungan yang negatif.

Dalam penelitian ini terdapat lingkungan institusional lemah dan lingkungan institusional kuat. Berdasarkan penelitian sebelumnya bahwa opini audit diduga memiliki yang negatif dengan lingkungan institusionalnya. Opini wajar tanpa pengecualian akan lebih mudah diperoleh perusahaan yang berada pada lingkungan institusional lemah karena perusahaan akan mudah memilih auditoryang diinginkan disebabkan oleh lemahnya pengendalian lingkungan hukum. Sedangkan untuk memperoleh opini wajar tanpa pengecualian pada perusahaan di lingkungan institusional kuat akan lebih sulit, disebabkan karena kebebasan untuk memilih auditor dibatasi oleh lingkungan hukum yang kuat pula. Sehingga, penelitian ini mengangkat hipotesis sebagai berikut :

$\mathrm{H}_{1}$ : Lingkungan institusional lemah berpengaruh terhadap pendapat wajar tanpa pengecualian pada perusahaan manufaktur, dibandingkan dengan lingkungan institusional yang kuat. 
Kondisi keuangan merupakan gambaran kondisi perusahaan secara nyata, bagaimana kinerja perusahaan. Keadaan suatu perusahaan dapat dikatakan baik atau buruk dapat dilihat pada rasio keuangan sebagai salah satu standarnya. Menurut Setiyanti (2010) bahwa kondisi keuangan merupakan tolak ukur utama baik buruknya kinerja keuangan perusahaan dan konsisi keuangan yang baik memungkinkan auditor eksternal memberikan opini Unqualified (Wajar Tanpa Pengecualian/WTP)

Menurut Dewayanto (2011) bahwa keadaan keuangan suatu perusahaan dalam kurun waktu tertentu merupakan gambaran dari kondisi keuangan suatu perusahaan. Menurut Ramadhany (2004) bahwa tingkat kesehatan suatu perusahaan yang sebenarnya dapat digambarkan pada kondisi keuangan suatu perusahaan.Pengelolaan keuangan suatu perusahaan dilakukan oleh pihak manajemen sebagai agent. Diperlukan pihak ketiga yang dianggap mampu untuk menghubungkan antara pemilik perusahaan sebagai principal dengan pihak manajemen, dalam hal ini adalah auditor keuangan sebagai pihak yang netral dalam melakukan pemeriksaan terhadap laporan keuangan perusahaan.

Pernyataan yang wajar terhadap suatu laporan keuangan yang diberikan oleh seorang auditor yang mencerminkan kinerja keuangan suatu perusahaan menjadi data/informasi yang dapat meningkatkan kepercayaan para pengguna laporan keuangan, termasuk para investor (Sari, 2010).

Beberapa penelitian tentang kinerja keuangan telah dilakukan. Kartika, (2012) menemukan bahwa peluang suatu perusahaan untuk menerima opini audittidak di pengaruhi oleh kondisi keuangan secara signifikan. Penelitian 
Yanuariska dan Ardiati (2018) bahwa opini audit dengan kondisi keuangan memiliki hubungan yang positif. Menurut penelitian yang dilakukan Putrady dan Haryanto (2014) bahwa probabilitas penerimaan opini audit dipengaruhi secara signifikan oleh kondisi keuangan suatu perusahaan. Adapun penemuan yang lain yaitu penemuan oleh Aprinia dan Hermanto (2016) menyatakan bahwa opini auditor secara signifikan dipengaruhi oleh rasio likuiditas. Ardiani et al. (2012) menemukan bahwa penerimaan opini audit tidak mempengaruhi kondisi keuangan suatu perusahaan.

$\mathrm{H}_{2}$ : Kondisi keuangan berpengaruh positif terhadap penerimaan opini audit.

\section{METODE PENELITIAN}

Jenis penelitian yang digunakan dalam penelitian ini adalah penelitian asosiatif dengan hubungan kausal. Penelitian asosiatif adalah penelitian yang mencari hubungan antara variable yang satu dengan variable yang lainnya. Dalam penelitian ini penulis menggunakan hubungan kausal, yaitu untuk mengidentifikasikan hubungan sebab akibat antara variable-variabel dependen dan variable independen (Sugiyono, $2013: 37$ ).

Obyek penelitian dalam penelitian ini yaitu perusahaan manufaktur yang listing pada Bursa Efek Indonesia (BEI) periode tahun 2017. Data yang digunakan dalam penelitian yakni data sekunder, yang diperoleh melalui website resmi seperti www.idx.com dan website resmi perusahaan yang menjadi sampel poenelitian. 
Populasi adalah wilayah generalisasi yang terdiri dari orang atau obyek yang mempunyai kualitas dan karakteristik tertentu yang ditetapkan oleh peneliti untuk dipelajari dan kemudian ditarik kesimpulannya (Sugiyono, 2014:80). Populasi yang digunakan dalam penelitian ini adalah perusahaan manufaktur yang terdaftar di Bursa Efek Indonesia (BEI) pada tahun 2017.

Sampel merupakan bagian kecil dari populasi (Sugiyono, 2014:81) Sebuah sampel adalah bagian dari populasi keseluruhan yang dipilih secara cermat agar mewakili populasi, sehingga sampel harus representative terhadap populasi. Purposive sampling method merupakan metode pengambilan sampel yang digunakan dalam penelitian ini. Tabel 1 terdapat beberapa syarat penentuan sampel penelitian yang digunakan .

Tabel 1.

Penyaringan Populasi dan Sampel Penelitian

\begin{tabular}{lcc}
\hline \multicolumn{1}{c}{ Keterangan } & Jumlah & Akumulasi \\
\hline Jumlah perusahaan manufaktur yang terdaftar di BEI & 154 & 154 \\
Jumlah perusahaan manufaktur yang tidak melaporkan laporan & $(3)$ & 151 \\
tahunan pada tahun 2017 & & \\
Jumlah Perusahaan yang tidak menampilkan opini auditor & $(4)$ & 147 \\
Jumlah Perusahaan yang tidak menampilkan Laporan Keuangan & $(1)$ & 146 \\
Jumlah sampel sesuai dengan kriteria & & \multicolumn{2}{c}{146} \\
\hline
\end{tabular}

Sumber: Data diolah, 2019

Berdasarkan kriteria sampel yang telah ditentukan maka diperoleh 146 sampel. Penelitian ini bermaksud untuk menjelaskan pengaruh lingkungan institusional, tipe auditor dan kinerja keuangan terhadap opini auditor. Alat analisis regresi logistik (logistic regression) digunakan sebagai metode untuk menguji hipotesis dalam penelitian ini.

Kondisi keuangan merupakan gambaran kondisi perusahaan secara nyata, bagaimana kinerja perusahaan. Menurut Setiyanti (2010) bahwa kondisi keuangan 
merupakan tolak ukur utama baik buruknya kinerja keuangan perusahaan dan konsisi keuangan yang baik memungkinkan auditor eksternal memberikan opini Unqualified (Wajar Tanpa Pengecualian/WTP). Kondisi keuangan juga merupakan suatu tampilan secara utuh atas keuangan perusahaan. Dalam memprediksi kinerja keuangan suatu perusahaan, penulis menggunakan model Altman.

Model Altman (1968) menemukan bahwa perusahaan dengan profitabilitas serta solvabilitas yang rendah sangat berpotensi mengalami kebangkrutan. Altman mengembangkan model kebangrutan dengan menggunakan 22 rasio keuangan yang diklasifikasikan kedalam lima kategori yaitu likuiditas, profitabilitas, leverage, rasio uji pasar dan aktivitas.

Model Altman Revised (1993) merupakan revisi dari model sebelumnya dengan tujuan agar model prediksinya tidak hanya digunakan pada perusahaan manufaktur tetapi juga dapat digunakan untuk perusahaan selain manufaktur. Dalam memprediksi kinerja keuangan suatu perusahaan, penulis menggunakan model revised Edward Altman yang terkenal dengan nama $Z$ Score, dimana formulanya adalah :

$$
Z^{\prime}=0.717 Z_{1}+0.874 Z_{2}+3.107 Z_{3}+0.420 Z_{4}+0.998 Z_{5}
$$

Keterangan:

Z' : Overall Index (indeks keseluruhan)

$\mathrm{Z}_{1}$ : Net Working Capital to Total Assets Ratio (Modal Kerja Bersih /Total Aktiva)

$\mathrm{Z}_{2}$ : Retained Earnings in Total Assets (Laba Ditahan/Total Aktiva)

$\mathrm{Z}_{3}$ : $\quad$ Earning Before Interest and Taxes to Total Assets (Laba Sebelum Bunga dan Pajak/Total Aktiva)

$\mathrm{Z}_{4}$ : $\quad$ Book Value of Equity to Book Value of Liabilities (Nilai Buku Modal Sendiri/Nilai Buku Hutang) 


\section{$\mathrm{Z}_{5}: \quad$ Sales/total asset}

Suatu perusahaan dalam model Z Score dapat dikatakan sehat apabila nilai Z' score lebih dari 2,99 (Solikhah, 2010). Hal ini menunjukkan bahwa semakin besar nilai Z' Score suatu perusahaan, maka kinerja keuanganyna semakin bagus, demikian pula halnya apabila nilai Z' Score semakin kecil menunjukkan bahwa kinerja keuangan semakin menurun.

Beberapa tahapan yang dilakukan untuk menguji hipotesis analisis regresi logistik menurut (Ghozali (2016) dalam penelitian ini meliputi uji kelayakan model regresi logistik dengan menggunakan Goodness of fit test yang diukur dengan Chi-Square pada tabel Hosmer dan Lemeshow. Kemudian uji keseluruhan model regresi (overall fit model) yaitu digunakan untuk menguji keberartian model regresi logistik, statistik Uji G dan Uji Wald (W) untuk menentukan taraf nyata (signifikansi) suatu model dan parameter secara keseluruhan dan secara parsial (individual) dimana kedua alat uji itu identik dengan Uji F dan Uji T pada Regresi Linear yang menggunakan Ordinary Least Square (Hendayana, 2013).

Menurut Utoyo (2006), untuk menentukan tingkat signifikansi secara simultan dapat dilihat pada tabel output Omnibus Test Of Model Coefficien. Kemudian koefisien determinasi pada regresi logistik dapat dilihat pada nilai Nagelkerke's $R$ Square. Kemudian mencari adanya korelasi antara variabel independen (bebas) adalah dengan cara uji multikolonierisme dengan menggunakan matrik korelasi, apabila nilai koefisien korelasi antar variabel bebas lebih kecil dari 0,8 berarti tidak terdapat gejala multikolinearitas yang serius antar variabel bebas tersebut (Kuncoro, 2004). Lalu kemudian menghitung nilai 
estimasi yang benar (correct) dan yang salah (incorrect) dengan menggunakan Tabel klasifikasi (Classification Table). Dan yang terakhir melakukan estimasi parameter yang ditunjukkan melalui koefisien regresi. Formula yang digunakan adalah sebagai berikut:

$\mathrm{OPN}=\beta_{0}+\beta_{1} \mathrm{INS}+\beta_{2} \mathrm{LOC}+\beta_{3} \mathrm{FIN}+\mathrm{e}$

Keterangan:

$\mathrm{P} \quad$ : Logistic Distribution Function, yaitu probabilitas opini WTP

OPN : Opinion (dummy Variabel; OPN $=1$ apabila opini $\mathrm{WTP}, \mathrm{OPN}=0$ apabila opini non WTP)

INS : Lingkungan Insitusional (Dummy Variabel; kuat=1, lemah=0)

LOC : Tipe Auditor (DummyVariabel; dimana auditor lokal $=1$, auditor non lokal $=0$ )

FIN : Kondisi keuangan perusahaan

\section{HASIL DAN PEMBAHASAN}

Setelah dilakukan penyaringan sampel sesuai standar yang telah ditentukan, maka diperoleh sampel penelitian ini sejumlah 146 perusahaan manufaktur yang terdaftar pada Bursa Efek Indonesia pada tahun 2017. Pada Tabel 2 ditampilkan hasil pengolahan data yang telah dilakukan.

Tabel 2.

Rincian Perusahaaan Sampel Berdasarkan Lingkungan Institusional dan Opini Auditor

\begin{tabular}{lccccccc}
\hline \multirow{2}{*}{ Keterangan } & \multicolumn{3}{c}{ Opini WTP } & \multicolumn{3}{c}{ Opini Non WTP } \\
\cline { 2 - 7 } & Frekwensi & $\begin{array}{c}\text { Persentas } \\
\text { e }(\%)\end{array}$ & Total & $\begin{array}{c}\text { Frekwen } \\
\text { si }\end{array}$ & $\begin{array}{c}\text { Persentas } \\
\text { e (\%) }\end{array}$ & Total \\
\hline Lingkungan & Kuat & 68 & 46,90 & 124 & 14 & 17,08 & 22 \\
Institusional & Lema & 56 & 38,36 & & 8 & 12,50 & \\
\cline { 2 - 7 } & $\mathrm{h}$ & & & & & &
\end{tabular}

Pada Tabel 2 dapat dijelaskan bahwa kuantitas perusahaan manufaktur yang berada pada lingkungan institusional kuat sejumlah 82 perusahaan sedangkan yang berada pada lingkungan institusional lemah sejumlah 64 
perusahaan. Dari angka tersebut mengandung arti bahwa pada lingkungan institusional lemah memiliki jumlah perusahaan lebih sedikit dibandingkan dengan jumlah perusahaan manufaktur yang berada pada lingkungan institusional kuat.

Menurut pengamatan yang telah dilakukan, diperoleh hasil yang menunjukkan bahwa opini audit Wajar Tanpa Pengecualian (WTP) pada Lingkungan Institusional (INS), dimana lingkungan institusional kuat memiliki frekwensi yang lebih tinggi yaitu sebesar 124 kali dibandingkan dengan lingkungan institusional lemah yang hanya sebesar 14 kali. Sementara opini audit Non WTP pada lingkungan institusional kuat memiliki frekwensi sebesar 22 kali, sedangkan frekwensi terjadinya opini Non WTP pada lingkungan institusional lemah hanya 8 kali. Hal ini menunjukkan bahwa tingkat penerimaan opini auditor Non WTP suatu perusahaan lebih rendah dibandingkan dengan tingkat penerimaan opini WTP. Tingkat penerimaan opini WTP yang terjadi pada perusahaan yang berada pada lingkungan instutusional kuat lebih banyak dibandingkan dengan perusahaan pada lingkungan institusional lemah.

Berdasarkan hasil penelitian yang telah dilakukan, kemudian disajikan Tabel kontigensi untuk melihat probabilitas hubungan antara variabel opini auditor (WTP dan Non WTP), lingkungan institusional (Kuat dan Lemah). Tabel kontijensi ditampilkan pada Tabel 3 sebagai berikut :

Tabel 3.

Tabel Kontijensi Opini Auditor, Lingkungan Institusional

\begin{tabular}{ccccc}
\hline No & Keterangan & \multicolumn{3}{c}{ Lingkungan Institusional } \\
\cline { 3 - 5 } 1 & & Kuat & Lemah & Total \\
2 & WTP & 68 & 56 & 124 \\
& No WTP & 14 & 8 & 22 \\
& Total & 82 & 64 & 146 \\
\hline
\end{tabular}


Sumber: Data diolah, 2019

Berdasarkan hasil klasifikasi terdapat beberapa kemungkinan probabilitas terjadinya suatu perusahaan memperoleh opini WTP maupun opini Non WTP. Probabilitas bahwa perusahaan pada Lingkungan Institusional akan menerima Opini WTP adalah 124/146 atau 0,85, artinya bahwa peluang suatu perusahaan berdasarkan Lingkungan Institusional akan menerima Opini WTP adalah sebesar 0,85. Probabilitas bahwa perusahaan pada Lingkungan Institusional akan menerima WTP dan perusahaan tersebut berada pada lingkungan Institusional Kuat $(\mathrm{K})$ adalah $68 / 82$ atau 0,83 , artinya bahwa peluang suatu perusahaan yang berada pada Lingkungan Institusional Kuat untuk menerima Opini WTP adalah sebesar 0,83. Probabilitas bahwa perusahaan pada Lingkungan Institusional akan menerima WTP dan perusahaan tersebut berada pada lingkungan Institusional Lemah (L) adalah 56/64 atau 0,875, artinya bahwa peluang suatu perusahaan yang berada pada Lingkungan Institusional Lemah untuk menerima Opini WTP adalah sebesar 0,83 .

Sebagaimana probabilitas, dalam model Logistic Regression untuk melihat peluang terjadinya suatu perusahaan mendapatkan Opini WTP maka digunakan Odds yang menggambarkan probabilitas. Dari Tabel 3 dapat ditentukan nilai Odds suatu variabel. Odds suatu perusahaan yang berada pada Lingkungan Institusional (INS) akan menerima WTP adalah 124/22 atau 5,63 yang berarti bahwa Odds suatu perusahaan pada Lingkungan Institusional akan menerima Opini WTP adalah 5,63 kali dibandingkan dengan opini Non WTP. Odds suatu perusahaan yang berada pada Lingkungan Institusional kuat (K) akan menerima 
WTP adalah 68/14 atau 4,86 yang berarti bahwa Odds suatu perusahaan pada Lingkungan Institusional Kuat akan menerima Opini WTP adalah sebesar 4,86 kali dibandingkan dengan opini Non WTP. Odds suatu perusahaan yang berada pada Lingkungan Institusional Lemah (L) akan menerima WTP adalah 56/8 atau 7 yang berarti bahwa Odds suatu perusahaan pada Lingkungan Institusional Lemah akan menerima Opini WTP adalah 7 kali lebih besar dibandingkan dengan opini Non WTP.

Dalam memprediksi kinerja keuangan suatu perusahaan, penulis menggunakan model Altman. Model Altman. Altman mengembangkan model kebangrutan dengan menggunakan 22 rasio keuangan yang diklasifikasikan kedalam lima kategori yaitu likuiditas, profitabilitas, leverage, rasio uji pasar dan aktivitas.

Dalam memprediksi kinerja keuangan suatu perusahaan, penulis menggunakan model revised Edward Altman yang terkenal dengan nama $Z$ Score Kriteria titik cut off Model Z Score adalah bahwa suatu perusahaan dikatakan sehat apabila nilai Z' score lebih dari 2,99 (Solikhah, 2010). Hal ini menunjukkan bahwa semakin besar nilai Z' Score suatu perusahaan, maka kinerja keuanganyna semakin bagus, demikian pula halnya apabila nilai Z' Score semakin kecil menunjukkan bahwa kinerja keuangan semakin menurun. Nilai rata-rata kinerja keuangan perusahaan dapat dilihat pada nilai index Z'Score ditampilkan dalam Tabel 4 sesuai dengan hasil analisis yang telah dilakukan :

Tabel 4.

Hasil analisis Z' Score

\begin{tabular}{ccccc} 
Keterangan & Nilai minimum & Nilai Maksimum & Jumlah & Rata-rata \\
\hline Nilai Z' Score & $-10,39044$ & 10,35953 & 323.11462 & 2,21311 \\
\hline
\end{tabular}


Sumber : Data diolah, 2019

Variabel FIN memiliki nilai rata-rata sebesar 2,21311 dengan nilai minimum sebesar -10,39044 dan nilai maksimumnya 10,35953. Nilai rata- rata Z' Score menunjukkan nilai positif, hal ini mengambarkan banyak perusahaan sampel yang mengalami kondisi sehat, walaupun terdapat beberapa perusahaan yang memiliki nilai yang rendah sangat ekstrim. Nilai minimum dan maksimum yang dimiliki variabel menjelaskan bahwa nilai terendah dan nilai tertinggi dari Z' score perusahaan yang diteliti.

Regresi logistik menggunakan tabel Hosmer and Lemeshow dalam menilai apakah suatu model yang dibentuk layak atau tidak yang dikenal dengan nama Goodness of fit Test, adapun hasilnya ditunjukkan pada Tabel 5.

Tabel 5.

Hosmer and Lemeshow

\begin{tabular}{cccc}
\hline Step & Chi-square & df & Sig. \\
\hline 9.412 & & 8 & .309 \\
\hline Sumber $:$ Data diolah, 2019 & & &
\end{tabular}

Tingkat signifikansi pada nilai 0,309 lebih besar dari 0,05 , apabila nilai alfa 0,05 lebih kecil dari sinifikansinya, maka nilai observasinya mampu diprediksi oleh model yang dibentuk dengan kata lain hipotesis nol dapat diterima.

Penentuan taraf nyata (signifikansi) suatu model dan parameter dalam Regresi Logistik menggunakan statistik Uji G, dimana uji G ini menunjukkan tingkat signifikansi secara simultan Hasil pengujian keseluruhan model regresi ditunjukkan oleh tes koefisien model pada Tabel Omnibus berikut :

Tabel 6.

Hasil Tes Omnibus

\begin{tabular}{lrrrr}
\hline & & Chi-square & df & \multicolumn{2}{c}{ Sig. } \\
\hline Step & Step & 36.054 & 2 & .000
\end{tabular}




\begin{tabular}{|c|c|c|c|c|}
\hline \multirow[t]{2}{*}{1} & Block & 36.054 & 2 & .000 \\
\hline & Model & 36.054 & 2 & .000 \\
\hline
\end{tabular}

Hasil pengujian secara simultan menunjukkan nilai signifikansi 0,000 merupakan nilai signifikansi yang lebih rendah dari 0,05 , mengindikasikan bahwa secara simultan terdapat pengaruh yang signifikan dari variabel independen Lingkungan Institusional dan Kinerja Keuangan terhadap variabel dependen opini auditor WTP. Koefisien determinasi pada regresi logistik dapat dilihat pada nilai Nagelkerke R Square pada Tabel 7.

Tabel 7. Model Summary

\begin{tabular}{lrrr}
\hline $\begin{array}{l}\text { Ste } \\
\mathrm{p}\end{array}$ & -2 Log likelihood & Cox \& Snell R Square & Nagelkerke R Square \\
\hline 1 & $94.431^{\mathrm{a}}$ & .219 & .370 \\
\hline \multicolumn{2}{l}{ Sumber : Data diolah, 2019}
\end{tabular}

Nilai nagelkerke R Square dapat diinterpretasikan seperti nilai R Square pada regresi berganda (Ghozali, 2007). Nilai Nagelkerke R Square sebesar 0,370. Hal ini berarti bahwa variabilitas variabel dependen yang dapat dijelaskan oleh variabel independen adalah sebesar 37,7 persen, sedangkan sisanya sebesar 62,3 persen dijelaskan oleh variabel-variabel lain di luar model. Nilai ini hanya pendekatan saja, karena pada regresi logistik koefisien determinasi tidak dapat disamakan dengan regresi linier. Dalam regresi logistik, yang perlu diperhatikan adalah nilai Classification Plot yang terdapat pada Classification table, yang menunjukkan seberapa besar regresi model regresi mampu diprediksi Ghozali, 2016).

Tabel 8.

Classification Table

\begin{tabular}{ccc}
\hline Observed & \multicolumn{2}{c}{ Predicted } \\
\cline { 2 - 3 } & Opini Auditor & Percentage \\
\hline
\end{tabular}




\begin{tabular}{cccccc}
\hline \multirow{3}{*}{ Step 1 } & & & NON WTP & WTP & Correct \\
\cline { 2 - 6 } & Opini & Non WTP & 7 & 17 & 29.2 \\
& Auditor & WTP & 3 & 119 & 97.5 \\
& Overall Percentage & & & & 86.3 \\
\hline
\end{tabular}

Sumber : Data diolah, 2019

Secara keseluruhan model regresi logistik yang digunakan dalam penelitian ini adalah model yang baik, dimana model yang dihasilkan mampu mengestimasi dengan tingkat ketepatan sebesar $86,3 \%$. Hal ini menunjukkan bahwa probabilitas penerimaan opini audit wajar tanpa pengecualian (WTP) oleh suatu perusahaan adalah sebesar 0,86. Karena nilai Overall Percentage pada observasi mendekati nilai 1, sehingga model ini dapat dikatakan model yang baik. Nilainya ukuran asosiasi model suatu mendekati nilai 1, maka daya prediksi model tersebut dapat dikatakan semakin membaik (Hendayana, 2013).

Pengujian multikolinearitas dalam regresi logistik menggunakan matriks korelasi antara variabel bebas untuk melihat besarnya korelasi antara variabel bebas. Model regresi yang baik adalah regresi dengan tidak adanya gejala korelasi yang kuat di antara variabel bebasnya. Tabel 9 menunjukkan hasil analisis multikolonieritas model penelitian yang telah dilakukan.

Tabel 9.

Correlation Matrix

\begin{tabular}{ccccc}
\hline & & Constant & INS & FIN \\
\hline Step 1 & Constant & 1.000 & -.593 & -.596 \\
& INS & -.593 & 1.000 & -.022 \\
& FIN & -.596 & -.022 & 1.000 \\
\hline
\end{tabular}

Sumber : Data diolah, 2019

Pada tabel correlation matrix menunjukkan bahwa nilai koefisien korelasi antarvariabel masih dibawah angka 0,8, artinya bahwa tidak terdapat korelasi antara veriabel independen. Hal ini menunjukkan bahwa model regresi tersebut 
adalah model yang baik. Pengujian Hipotesis dapat dilihat pada tabel 10 berikut ini :

Tabel 10.

Variables in the Equation

\begin{tabular}{llrrrrrr}
\hline & & B & \multicolumn{1}{c}{ S.E. } & \multicolumn{1}{c}{ Wald } & df & \multicolumn{1}{c}{ Sig. } & \multicolumn{1}{c}{$\operatorname{Exp(B)}$} \\
\hline Step 1 $^{\text {a }}$ & INS & -.121 & .533 & .051 & 1 & .821 & .886 \\
& FIN & 1.022 & .242 & 17.802 & 1 & .000 & 2.780 \\
& Constant & .121 & .501 & .058 & 1 & .809 & 1.128 \\
\hline
\end{tabular}

Sumber : Data diolah, 2019

Model regresi logistik yang terbentuk adalah :

$$
\mathrm{y}=0,121-0,121 \mathrm{IN}+1,022 \mathrm{FIN}
$$

Hasil uji parsial diperoleh variabel INS Ho diterima, karena nilai uji Wald dimana nilai Wald lebih kecil dari nilai Chi Square dengan taraf nyata 0.05 adalah 3,84 atau nilai signifikansinya lebih besar dari alfa 0,05 sedangkan untuk variabel FIN Ho ditolak dimana nilai Wald lebih besar dari nilai Chi Square dengan taraf nyata 0.05 adalah3,84 atau nilai signifikansinya lebih kecil dari alfa 0,05. Tingkat sinifikansi yang diperoleh dari hasil uji hipotesis dengan cara membandingkan antara tingkat signifikansi (sig) pada tingkat kesalahan $\alpha=5 \%$, hanya Kinerja Keuangan (FIN) yang memiliki pengaruh signifikanpada nilai Sig $0.000<0.05$. Sedangkan Lingkungan Institusional (INS) memiliki Sig 0.821>0.05 yang artinya bahwa pengaruh Lingkungan Institusional (INS) terhadap Opini Auditor WTP tidak signifikan.

Hubungan antara Opini auditor WTP dengan Lingkungan Institusional ditunjukkan pada nilai koefisien yang negatif dengan koefisien INS sebesar 0,121. Data empiris menunjukkan sejumlah 68 perusahaan yang berada pada lingkungan institusional kuat mendapatkan Opini auditor WTP dari total 164 perusahaan, hubungan yang negatif ini mengandung arti bahwa semakin kuat 
suatu lingkungan institusional, maka semakin kecil kemungkinan untuk mendapatkan Opini Auditor WTP. Senada dengan hasil penemuan Chan et al., (2010) bahwa pada lingkungan intitusional yang lemah cenderung untuk mendapatkan opini auditor WTP dibandingkan dengan Lingkungan Institusional yang kuat. Dan penelitian Zahra dan Chariri (2013) menemukan pengaruh lingkungan institusional signifikan terhadap pemberian opini WTP oleh auditor dan memilikiasosiasi yang negatif.

Nilai koefisien Odds Ratio yaitu sebesar 0,89 mengandung arti bahwa peluang suatu perusahaan pada Lingkungan Institusional Kuat untuk mendapatkan Opini Auditor WTP adalah sebesar 0,89 kali dibandingkan dengan perusahaan pada Lingkungan Institusional Lemah. Sementara tingkat signifikansi yang dimiliki sebesar 0,821 yang artinya bahwa Lingkungan Institusional tidak berpengaruh secara signifikan, dengan kata lain bahwa lingkungan institusional tidak berpengaruh pada opini audit WTP.

Kinerja Keuangan dalam penelitian ini diukur dengan menggunakan Z' Score.Z' Score menunjukkan kondisi keuangan suatu perusahaan. Variabel Kinerja Keuangan yang memiliki koefisien positif sebesar 1,022 dengan tingkat signifikansi 0,000 yang berarti signifikan pada level 5\%, sehingga dapat disimpulkan bahwa variabel kinerja keuangan berpengaruh secara signifikan terhadap pemberian opini audit wajar tanpa pengecualian. Arah pengaruh yang positif mengandung arti bahwa setiap kenaikan nilai Kinerja Keuangan suatu perusahaan akan meningkatkan kemungkinan perusahaan untuk mendapatkan Opini Auditor WTP. Nilai Odds ratio sebesar 2,809 artinya bahwa resiko 
kecenderungan suatu perusahaan yang sehat untuk mendapatkan Opini Audit WTP adalah sebesar 2,809 kali dibandingkan dengan perusahaan yang tidak sehat.

Hasil penelitian ini menunjukkan bahwa auditor dalam menerbitkan opini audit WTP mempertimbangkan kondisi keuangan perusahaan. Hasil tersebut mendukung hipotesis kedua dalam penelitian ini. Hasil penelitian ini sejalan dengan hasil penelitian Yanuariska dan Ardiati (2018) bahwa kondisi keuangan berpengaruh positif terhadap opini audit. Menurut penelitian yang dilakukan Putrady dan Haryanto (2014) menemukan bahwa kondisi keuangan dengan menggunakan model Altman Score (Altman Revised) memiliki pengaruh yang signifikan terhadap probabilitas.

\section{SIMPULAN}

Berdasarkan rumusan masalah, tujuan, landasan teori, hipotesis, dan hasil pengujian, maka dapat ditarik kesimpulan penelitian sebagai berikut :Lingkungan Institusional tidak berpengaruh pada opini audit WTP. Hal ini berarti bahwa auditor dalam menerbitkan opini audit WTP tidak hanya mempertimbangkan bahwa perusahaan klien berada pada wilayah kota Jakarta atau bukan. Kinerja Keuangan berpengaruh secara signifikanterhadap opini audit WTP. Hal ini menunjukkan bahwa semakin besar nilai kinerja keuangan suatu perusahaanmaka semakin besar pula probabilitas suatu perusahaan untuk mendapatkanopini WTP.

Saran-saran yang dapat disampaikan berdasarkan penelitian ini dapat dijadikan sebagai bahanpengembangan pada penelitian selanjutnya.adalah sebagai berikut : pada penelitian mendatang bisa dilakukan pada obyek yang berbeda, 
misalnya dilakukan pada perusahaan sektor keuangan, variabel lingkungan institusional diukur dengan menggunakan variabel dummy sebaiknya penelitian berikutnya dapat mempertimbangkan proksi lain yang dapat mengukur lingkungan institusional dengan lebih tepat sehingga ditemukan hasil bahwa lingkungan institusional berpengaruh pada opini WTP, penelitian ini mengukur kinerja keuangan perusahaan menggunakan Z' Score disarankan untuk mencoca menggunakan alat ukur yang lain selain Z' Score.

\section{REFERENSI}

Agoes,S. 2012. Auditing (Petunjuk praktis pemeriksaan akuntan oleh akuntan publik). Jakarta, Indonesia: Salemba Empat.

Altman, E. I. (2007). The Journal of FINANCE. The Journal OfFinance, 23(4), 589-609. Retrieved from http://links.jstor.org/sici?sici=00221082\%28196809\%2923\%3A4\%3C589\%3AFRDAAT\%3E2.0.CO\%3B2-R

Aprinia, rizki wulan, \& Hermanto, suwardi bambang. (2016). PENGARUH Rasio Keuangan, Ukuran Perusahaan , Dan Reputasi Auditor Terhadap Opini Going Concern. Jurnal Ilmu Dan Riset Akuntansi, 5(9), 1-20

Ardiani, N., Dp, Emrinaldi Nur, \& Azlina, N. (2012). Pengaruh audit tenure, disclosure, ukuran KAP, debt default, opinion shopping, dan kondisi keuangan terhadap penerimaan opini audit going concern pada perusahaan real estate dan property di BEI. Jurnal Ekonomi, 20(4), 1-21.

Chan, K. H., Lin, K. Z., \& Mo, P. L.-L. (2006). A political-economic analysis of auditor reporting and auditor switches. Review of Accounting Studies, 11(1), 21-48. https://doi.org/10.1089/jam.2006.19.21

Chan, K. H., Lin, K., \& Lin, K. Z. (2010). The impact of government ownership and institutions on the reporting behavior of local auditors in China, 9, 1-20. https://doi.org/10.2308/jiar.2010.9.2.1.

Alnıaçık, Ü., Alnıaçık, E., Akçin, K., \& Erat, S. (2012). Relationships Between Career Motivation, Affective Commitment and Job Satisfaction. Procedia Social and Behavioral Sciences, 58, 355-362.

Buchari, A. (2011). Kewirausahaan. Bandung: Alfabeta. 
Budi, R., Dan, L., Wijaya, T., \& Mdp, S. (2012). Faktor Demografis (gender, latar belakang pendidikan orang tua, dan pengalaman bekerja) dapat Mempengaruhi Pilihan Karir MenjadiWirausahawan., 1(2), 112-119.

Chamberlain, J., Benson, L., Crockett, E., Thomas, T. P., Green, B. a, Chakabuda, T. C., ... Bahli, B. (2010). The Relationship between Career Choice and Individual Values: A Case Study of a Turkish University. Proceedings of the 12th IEEE International Conference on Advanced Learning Technologies, ICALT 2012, 04(3), 1-9.

Mulyadi. 2014. Auditing. Edisi keenam. Jakarta: Salemba Empat.

Putrady, C. P. \& Haryanto (2014).Analisis Faktor Keuangan dan Non Keuangan Yang Mempengaruhi Penerimaan Opini Audit Going Concern.Diponegoro Journal of Accounting Vol 3 No 2, hal 1-12. Muchlis, tanti irawati, \& Jayanti, kurniasari dian. (2010). Bankruptcy risk analysis of properti sector listed companies in Indonesia stock exchange using altman z-score. Spring, 9, 92-106.

Ramadhany, Alexander. 2004. "Analisis Faktor-faktor yang Mempengaruhi Penerimaan Opini Going Concern pada Perusahaan Manufaktur yang mengalami Kondisi keuangan di Bursa Efek Jakarta “.Jurnal MAKSI. Agustus, Vol.4, pp : $146-160$

Sari, K., \& Rahardja, S. (2010). Analisis Pengaruh Audit Tenure, Reputasi Kap, Disclosure, Ukuran Perusahaan Dan Likuiditas Terhadap Penerimaan Opini Audit Going Concern.

Hisrich, R. ., Peters, M. ., \& Shepherd, D. (2008). Kewirausahaan. (S. Empat, Ed.) (7th ed.). Jakarta Setyanti, sri wiranti. (2010). Pengaruh kinerja keuangan perusahaan dan opini audit tahun sebelumnya terhadap opini audit mengenai going concern. Jurnal

Solikhah, B., \& Kiswanto. (2010). Pengaruh Kondisi Keuangan, Pertumbuhan dan Opini Audit Tahun Sebelumnya Terhadap Opini Audit Going Concern. Jurnal Dinamika Akuntansi, 2(1), 56-64.

Stanislaus S Uyanto. (2009). Pedoman Analisis Data dengan SPSS (3rd ed.). yogyakarta Indonesia: Graha Ilmu.

Tyagi, V. (2014). "A Study To Measures The Financial Health Of Selected Firms With Special Reference To Indian Logistic Industry/ : An Application of Altman's Z Score”. IISTE Journals. Vol 4 No 4. pp. 43-53

Yanuariska, M. D., \& Ardiati, A. Y. (2018). Pengaruh Kondisi Keuangan , Audit Tenure, dan Ukuran KAP terhadap Opini Audit Going Concern pada 
Perusahaan Manufaktur yang Terdaftar di BEI Tahun 2012-2016, 7(2), 117128. https://doi.org/10.30588/jmp.v7i2.361

Kurniawan, A. R. (2014). Pengaruh Motivasi Karir, Motivasi Ekonomi, dan Motivasi Gelar pada Minat Mahasiswa Akuntansi mengikuti PPAk.

Kusumastuti, R., \& Waluyo, I. (2019). Pengaruh Motivasi Dan Pengetahuan Uu No.5 Tahun 2011 Tentang Akuntan Publik terhadap Minat Mahasiswa Akuntansi Mengikuti Pendidikan Profesi Akuntansi (PPAk). Nominal, Barometer Riset Akuntansi Dan Manajemen, 2(2), 1-30.

Lee, S. H., \& Wong, P. K. (2004). An Exploratory Study of Technopreneurial Intentions: A Career Anchor Perspective. Journal of Business Venturing.

Lestari, R. B. (2012). Pengaruh Pendidikan Kewirausahaan terhadap Minat Berwirausaha Mahasiswa di STIE MDP, STMIK MDP, dan STIE MUSI. Forum Bisnis Dan Kewirausahaan Jurnal Ilmiah STIE MDP Hal -112.

DiMaggio, P. J., \& Powell, W. W. (2003). -IronCageRevisited-ASR. JSTOR. Retrieved from http://links.jstor.org/sici?sici=0003$1224 \% 28198304 \% 2948 \% 3 \mathrm{~A} 2 \% 3 \mathrm{C} 147 \% 3 \mathrm{ATICRII} \% 3 \mathrm{E} 2.0 . \mathrm{CO} \% 3 \mathrm{~B} 2-\mathrm{S}$

Edi dan Tania, M. (2018). Ketepatan model altman, springate, zmijewski, dan grover dalam memprediksi financial distress, (April). https://doi.org/10.22219/jrak.v8i1.28.

Hendayana, R. (2013). Application Method of Logistic Regression Analyze the Agricultural Technology Adoption. Informatika Pertanian, 22(1), 1-9. Retrieved from http://ejurnal.litbang.pertanian.go.id/index.php/IP/article/view/2271/1970

Hosmer, david w., \& Lemeshow, S. (2007). Applied logistic regression. Journal of Environmental Health. https://doi.org/10.1198/tech.2002.s650

Institut Akuntan Publik Indonesia. (2011), Standart Profesional Akuntan Publik. Jakarta. http://www.iapilib.com/spap/1/files/SA\%20700/SA\%20705.pdf

Jensen, M. C., \& Meckling, W. H. (1976). Theory of the firm: Managerial behavior, agency costs and ownership structure. Journal of Financial Economics. https://doi.org/10.1016/0304-405X(76)90026-X

Jensen, M. C., \& Meckling, W. H. (n.d.). Theory of the Firm: Managerial Behavior, Agency Costs and Ownership Structure. 
Mos Indrawati, H. Ahmad Eifai dan M. Irawan, MP. Pengaruh ...

Zahra, K. A., \& Chariri, A. (2013). Pengaruh Lingkungan Institusional Dan Tipe Auditor Terhadap Opini Audit. Diponegoro Journal Of Accounting, 2(3), 113. Retrieved from http://ejournal-s1.undip.ac.id/index.php/accounting.

https://www.idx.co.id 